Vol. 2 No. 1 Februari 2022, e-ISSN : 2797-0140 | p-ISSN : 2797-0590

\title{
PENGEMBANGAN GAME KAHOOT SEBAGAI MEDIA EVALUASI HASIL BELAJAR SISWA
}

\author{
ARIEF MASYRUFIN \\ SMA Negeri 1 Malinau \\ E-mail : ariefmasvien03@gmail.com
}

\begin{abstract}
ABSTRAK
Perkembangan teknologi yang semakin pesat dapat dijadikan suatu inovasi yang dapat mendukung optimalisasi dalam evaluasi pembelajaran yang efektif, karena teknologi menawarkan berbagai macam kemudahan didalammnya. Pemanfaatan dan penggunaan teknologi dalam proses pembelajaran mampu memaksimalkan kegiatan belajar siswa. Salah satu bentuk pemanfaatan kemajuan tekonologi dalam dunia pendidikan yaitu aplikasi pembelajaran Kahoot. Model pengembangan yang digunakan peneliti yaitu model 4D, terbentuk dari 4 tahapan utama seperti : define, design, development, dan disseminate. Hasil validasi oleh ahli materi memperoleh persentase $80 \%$ "valid". Ahli media mendapatkan persentase $84 \%$ “valid". Ahli evaluasi mendapatkan persentase $80 \%$ "valid". Selanjutnya hasil uji coba didapatkan rata-rata nilai pretest siswa 42 dan posttest 88 terdapat peningkatan nilai sebesar 46. Terakhir penilain respon siswa terhadap penggunaan game Kahoot memperoleh persentase 92\% "sangat baik". Sehingga dapat disimpulkan aplikasi game Kahoot! yang dikembangkan peneliti relevan dan menarik untuk dijadikan sebagai media evaluasi hasil belajar siswa.
\end{abstract}

Kata Kunci : Game Kahoot, Media Evaluasi, Hasil Belajar.

\section{ABSTRACT}

The increasingly rapid development of technology can be used as an innovation that can support optimization in the evaluation of effective learning, because technology offers various kinds of convenience in it. Utilization and use of technology in the learning process is able to maximize student learning activities. One form of utilizing technological advances in education is the Kahoot learning application. The development model used by the researcher is the 4D model, formed from 4 main stages such as: define, design, development, and disseminate. The results of the validation by material experts obtained a percentage of $80 \%$ "valid". Media experts get a percentage of $84 \%$ "valid". Evaluation experts get a percentage of $80 \%$ "valid". Furthermore, the test results obtained an average score of 42 students pretest and posttest 88 there was an increase in the value of 46 . Finally, the assessment of student responses to the use of the Kahoot game obtained a percentage of $92 \%$ "very good". So it can be concluded that the game application Kahoot! developed by researchers is relevant and interesting to serve as a medium for evaluating student learning outcomes.

Keywords: Kahoot Game, Evaluation Media, Learning Outcomes.

\section{PENDAHULUAN}

Pada saat ini dunia pendidikan terus mengalami perkembangan, hal ini dapat disebabkan oleh beberapa faktor. Salah satunya yaitu tekonologi, perkembangan tekonologi tidak dapat dihindari khususnya dalam dunia pendidikan. Teknologi dapat mendukung proses pembelajaran, dengan teknologi pembelajaran dapat menjadi lebih efektif dan menarik. Pembelajaran berbasis teknologi saat ini dapat merangsang siswa untuk lebih semangat dalam belajar dan mengerjakan berbagai macam latihan soal, dikarenakan pembelajaran berbasis teknologi terdapat berbagai macam bentuk animasi, penjelasan berupa grafik, dan beragam warna yang menambah kesan nyata (Azhar, 2013). Dapat ditarik kesimpulan bahwa pembelajaran dapat disajikan secara modern dengan memanfaatkan kemajuan teknologi yang dapat mengembangkan potensi siswa. Terlebih lagi pada masa pandemi yang mengharuskan 
pembelajaran melalui online, teknologi khususnya handphone dan laptop menjadi komponen penunjang utama berlangsungnya proses pembelajaran jarak jauh.

Pengaruh pendidikan yang besar terhadap suatu individu maupun bangsa mengharuskan Pendidikan untuk dapat terus ditingkatkan kualiatasnya. Salah satu yang dapat dilakukan untuk bisa meningkatkan pendidikan yaitu dengan cara membuat media evaluasi hasil belajar siswa. Evaluasi merupakan suatu kegiatan untuk mendapatkan informasi mengenai hasil belajar siswa secara menyeluruh (Nuriyah, 2014). Dengan tujuan merefleksi dan mengetahui berhasil tidaknya proses pembelajaran yang sudah dilakukan.

Mata pelajaran Informatika merupakan mata pelajaran yang bersifat terapan, sehingga dalam proses pembelajarannya tidak hanya menggunakan konsep teoritis tetapi juga disertai dengan praktik. Tetapi pada kenyataannya tidak semua siswa dapat mencapai hasil yang diharapkan. Kondisi ini menunjukkan bahwa masih banyak faktor-faktor yang mempengaruhi kesulitan belajar tersebut. Diduga bahwa faktor tersebut berasal dari anak didik, sekolah, keluarga dan masyarakat sekitar.

Perkembangan teknologi yang semakin pesat dapat dijadikan suatu inovasi yang dapat mendukung optimalisasi dalam evaluasi pembelajaran yang efektif, karena teknologi menawarkan berbagai macam kemudahan didalamnya. Pemanfaatan dan penggunaan teknologi dalam proses pembelajaran mampu memaksimalkan kegiatan belajar siswa (Chairudin \& Dewi, 2021). Salah satu bentuk pemanfaatan kemajuan tekonologi dalam dunia pendidikan yaitu aplikasi pembelajaran Kahoot!. Menurut (Iwamoto et al., 2017) Kahoot! adalah sebuah aplikasi online yang dapat mengembangkan dan mempresentasikan soal-soal dalam suatu format "game-show". Sedangkan menurut (Graham, 2015) Kahoot! merupakan media pembelajaran online yang berisi pertanyaan gratis atau tidak berbayar yang diaplikasikan dalam proses pembelajaran dalam rangka mengevaluasi hasil belajar siswa.

Aplikasi game Kahoot! berisikan soal-soal dalam tampilan game-show yang dapat digunakan secara gratis atau tidak berbayar. Tampilan soal dalam aplikasi ini dapat dilengkapi dengan gambar maupun video yang dapat memperjelas soal. Pengoperasian aplikasi game Kahoot! ini sangat mudah dilakukan, Kahoot! dapat diakses melaui aplikasi maupun situs web sehingga menjadikannya praktis untuk digunakan. Sistem evaluasi menggunakan aplikasi game Kahoot! memungkinkan guru untuk dapat langsung mengetahui hasil belajar siswa, karena dalam aplikasi game Kahoot! point yang diperoleh siswa dapat langsung ditampilkan setelah siswa menjawab soal.

Selain itu, dalam pengembangan aplikasi Kahoot! ini mengutamakan keterlibatan hubungan peran aktif siswa dengan dengan temannya secara kompetitif mengenai materi pelajaran yang masih atau sudah dipelajari (Ishak, 2017). Kelebihan lain yang dimiliki oleh Kahoot! yaitu hasil perolehan poin siswa dalam menjawab soal langsung dapat ditampilkan dilayar, sehingga dapat menjadi media pengukuran hasil belajar siswa (Fitri Rofiarti \& Anisa Yunita Sari, 2017). Pada masa pandemi seperti saat ini Kahoot! dapat dijadikan sebagai alternatif media evaluasi bagi para guru yang diharuskan malaksanakan pembelajaran melalui daring.

Hasil penelitian (Sartika \& Octafiani, 2019) menunjukkan bahwa aplikasi Kahoot sangat layak digunakan sebagai alat evaluasi. Dikarenakan aplikasi Kahoot sangat membantu pembelajaran agar lebih menarik, tidak membosankan, dan lebih meningkatkan kreaktifitas dan keaktifan siswa. Kahoot merupakan aplikasi online dimana kita bisa membuat kuis dan menyajikannya dalam bentuk permainan, adapun poin yang diberikan dalam untuk jawaban yang benar bisa dilihat langsung oleh siswa. Pembelajaran berbasis permainan ini memiliki potensi untuk menjadi alat yang efektif karena merangsang komponen visual dan verbal (Iwamoto, Hargis, Taitano, \& Vuong, 2017).

Berdasarkan pemaparan latar belakang diatas rumusan masalah yang akan dibahas yaitu : (1) Bagaimana kelayakan game Kahoot! sebagai media evaluasi hasil belajar siswa di SMA Negeri 1 Malinau? (2) Bagaimana efektifitas aplikasi game Kahoot! sebagai media evaluasi 
hasil belajar siswa di SMA Negeri 1 Malinau? (3) Bagaimana respon siswa setelah mengunakan aplikasi game Kahoot! sebagai media evaluasi hasil belajar siswa di SMA Negeri 1 Malinau?

Sehingga berdasarkan latar belakang yang telah dijelaskan tersebut menjadi awal muculnya ide peneliti untuk melakukan sebuah penelitian pengembangan game Kahoot! sebagai media evaluasi hasil belajar siswa.

\section{METODE PENELITIAN}

Penelitian pengembangan R\&D (Research and Development) merupakan jenis penelitian yang digunakan. Kemuadian untuk model pengembangan yang dipilih yaitu model penelitian dan pengembangan model 4D. Pengembangan model 4D merupakan singkatan dari Define, Design, Development and Dissemination diadaptasi oleh (Thiagarajan, 1974). Pada dasarnya peneliti menggunakan pengembangan model 4D dikarenakan model ini memiliki tahapan yang sistematis dan sesuai untuk penelitian pengembangan. Bentuk produk dari pengembangan yang akan dihasilkan dari penelitian ini yaitu aplikasi game Kahoot! sebagai media evaluasi hasil belajar siswa.

Adapun tahapan dalam model penelitian 4D adalah sebagai berikut :

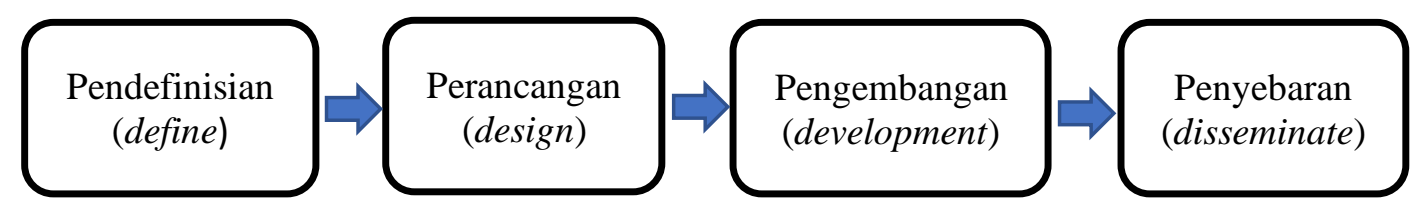

\section{Gambar 1. Tahapan Pengembangan Model 4D}

Pendefinisian (define) merupakan tahap untuk menentukan segala bentuk persyaratan yang dibutuhkan dalam pengembangan pembelajaran. Pada tahap ini juga peneliti menentukan mengenai produk yang akan dikembangkan.

Perancangan (design) merupakan tahap yang bertujuan untuk bisa menyiapkan media kuis interaktif berbasis game Kahoot sebagai media evaluasi hasil belajar siswa.

Pengembangan (development) merupakan tahap yang bertujuan untuk membuat draft menjadi suatu produk dan menguji validitasnya kepada para ahli dibidangnya. Setelah mengembangkan aplikasi game Kahoot! Sesuai dengan draft pada tahap desain selanjutnya produk yang telah dihasilkan tersebut dilakukan validasi kepada para ahli, seperti : ahli materi, media dan evaluasi. Sehingga pada tahap pengembangan ini menghasilkan aplikasi game Kahoot! sebagai media evaluasi hasil belajar yang layak untuk diuji coba pada siswa kelas XI MIPA 3 SMA Negeri 1 Malinau dengan pokok bahasan Integrasi antar office.

Penyebaran (disseminate) merupakan tahap yang bertujuan untuk menyebarluaskan hasil dari produk yang telah dikembangkan dalam jangkauan yang lebih luas dengan tujuan untuk menguji keefektifan penggunaan hasil produk yang dikembangkan. Tetapi, dalam penelitian dan pengembangan ini, peneliti hanya sebatas sampai pada tahap pengembangan (development) dikarenakan adanya keterbatasan waktu untuk penyebaran secara luas.

Penelitian ini dimulai dengan membagikan soal pretest kepada siswa, kemudian menjelaskan materi pelajaran konsep Integrasi antar office, jika dirasa siswa sudah paham selanjutnya peneliti menerapkan aplikasi game Kahoot! dalam pembelajaran. Terakhir dibagikan lagi soal kepada siswa sebagai posttest yang hasilnya akan dibandingkan untuk mengetahui tingkat kelayakan dari aplikasi game Kahoot! yang dikembangkan.

Subjek dalam penelitian ini diantaranya adalah : ahli materi dan soal Ibu Leny Christiana, S.Pd, ahli media Bapak Try Sudrajat, S.Pd, ahli evaluasi Bapak Sumardi, S.Pd, serta siswa XI MIPA 3 SMA Negeri 1 Malinau sebanyak 20 siswa.

Tabel 1. Kriteria Interpretasi Kelayakan

\begin{tabular}{|l|c|}
\hline \multicolumn{1}{|c|}{ Kriteria } & Persentase (\%) \\
\hline Sangat Tidak Layak & $0-20$ \\
\hline Tidak Layak & $21-40$ \\
\hline
\end{tabular}


Vol. 2 No. 1 Februari 2022, e-ISSN : 2797-0140 | p-ISSN : 2797-0590

\begin{tabular}{|l|c|}
\hline Cukup Layak & $41-60$ \\
\hline Layak & $61-80$ \\
\hline Sangat Layak & $81-100$ \\
\hline
\end{tabular}

Berdasarkan kriteria pada tabel 2 jika hasil dari respon siswa memperoleh hasil lebih dari $60 \%$ maka produk telah dapat digunakan oleh siswa.

Selanjutnya untuk mendapatkan hasil persentase ketuntasan klasikal siswa diperoleh menggunakan rumus dibawah ini :

$$
\text { Rumus }=\frac{\text { Jumlah Peserta Didik } \text { Tuntas }}{\text { Jumlah Peserta Didik }} \times 100
$$

Setelah hasil nilai diketahui perhitungan untuk mendapatkan nilai hasil belajar juga dapat diperoleh dengan rumus $N$-gain Skor sebagai berikut :

$$
\langle\mathrm{g}\rangle=\frac{\text { Nilai Sesudah-Nilai Sebelum }}{\text { Nilai Maksimal-Nilai Sebelum }}
$$

Nilai hasil belajar dapat dinyatakan meningkat apabila nilai $\mathrm{N}$-gain $>0.3$ dalam klasifikasi sebagai berikut :

Tabel 2

Klasifikasi Nilai Standar N-Gain

\begin{tabular}{|l|c|}
\hline \multicolumn{1}{|c|}{ Nilai Standard $\mathbf{N}$-Gain } & Klasifikasi \\
\hline $\mathrm{G}>0.7$ & Tinggi \\
\hline $0.7>\mathrm{g}>0.3$ & Sedang \\
\hline $\mathrm{G}<0.3$ & Rendah \\
\hline
\end{tabular}

\section{HASIL DAN PEMBAHASAN}

\section{Hasil Penelitian Pengembangan Game Kahoot!}

Dalam penelitian ini model pengembangan yang digunakan yaitu model $4 \mathrm{D}$, dengan tahapan sebagai berikut :

1. Tahap Pendefinisian (define)

Di tahap ini diperoleh suatu masalah yaitu sistem evaluasi di SMA Negeri 1 Malinau khususnya pada mata pelajaran informatika masih menggunakan sistem evaluasi konvensional. Dimana sistem evaluasi konvensional dirasa kurang cocok diterapkan pada pembelajaran daring seperti saat ini, karena terdapat banyaknya peluang siswa untuk melakukan kecurangan. Bentuk kecurangan tersebut dapat diketahui dari jawaban siswa saat mengerjakan soal yang rata-rata hasil jawabannya sama. Kecurangan seperti ini biasa dilakukan siswa dengan cara saling bertukan jawaban melalui whatsapp atau alat komunikasi lainnya. Sehingga menyebabkan hasil evaluasi yang diperoleh guru sudah tidak akurat lagi. Maka dari itu berdasarkan dari analisis karakteristik siswa, peneliti mengembangkan game Kahoot! sebagai media evaluasi hasil belajar yang bertujuan untuk mendukung optimalisasi dalam evaluasi pembelajaran agar lebih akurat dan efektif.

2. $\quad$ Tahap Perancangan (Design)

Pada tahap perancangan menghasilkan rancangan awal dari aplikasi game Kahoot! yang akan dikembangkan.

Dalam tahap perancangan ini terdapat 3 langkah, yaitu : a). Perancangan Kahoot!, hasilnya yaitu aplikasi game Kahoot! dapat diakses melalui aplikasi maupun web yang berisi 10 soal pilihan ganda dengan durasi waktu menyelesaikan soal 30-240 detik tergantung pada tingkat kesukaran soal, dimana skor tertinggi adalah 1000 setiap soalnya. b). Penyususnan tes, peneliti menyususan instrumen pengambilan data melalui tes hasil belajar dalam bentuk soal 
pilihan ganda yang berjumlah 10 yang akan dibagikan kepada siswa dengan tujuan untuk dapat mengetahui tingkat perubahan hasil belajar siswa yang didapatkan siswa sebelum dan sesudah menggunakan aplikasi game Kahoot sebagai media evaluasi, tes ini diberikan sebanyak 2 kali yaitu yang pertama (pretest) dan yang terakhir (posttest). c). Pemilihan format, pengembangan aplikasi Kahoot! soal yang disusun berkaitan dengan materi konsep integrasi office, setelah guru menjelaskan materi selanjutnya siswa akan diminta untuk login Kahoot! kemudian mengerjakan soal-soal yang ada didalam Kahoot! guru akan berperan sebagai operator yang menjalankan game Kahoot! selama siswa mengerjakan soal berupa kuis, jika semua soal telah diselesaikan siswa maka akan muncul point yang diperoleh oleh setiap siswa, selanjutnya guru bisa menganalisis dan mengevaluasi hasil belajar siswa pada materi konsep integrasi antar office.

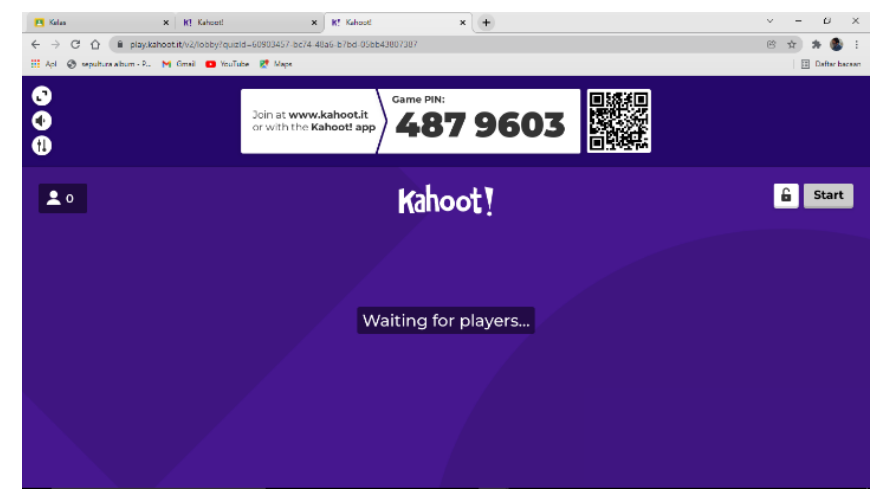

Gambar 2. Tampilan Awal Kahoot!

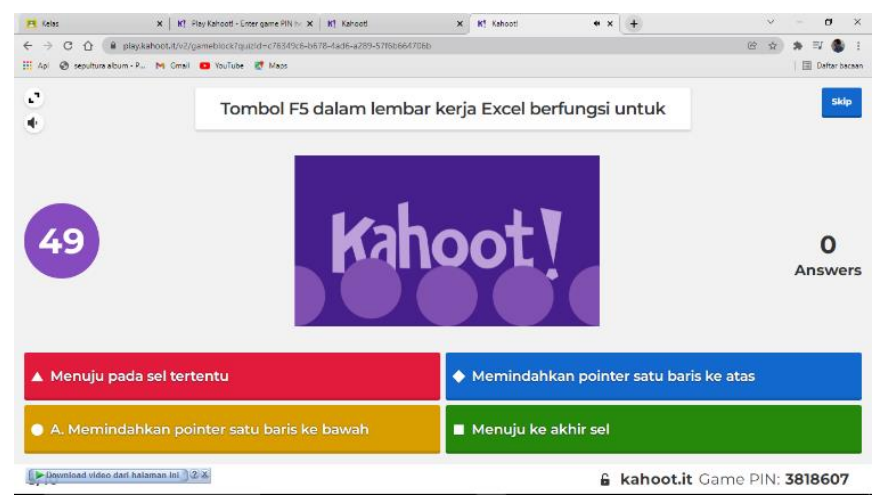

Gambar 3. Contoh Soal Pada Kahoot!

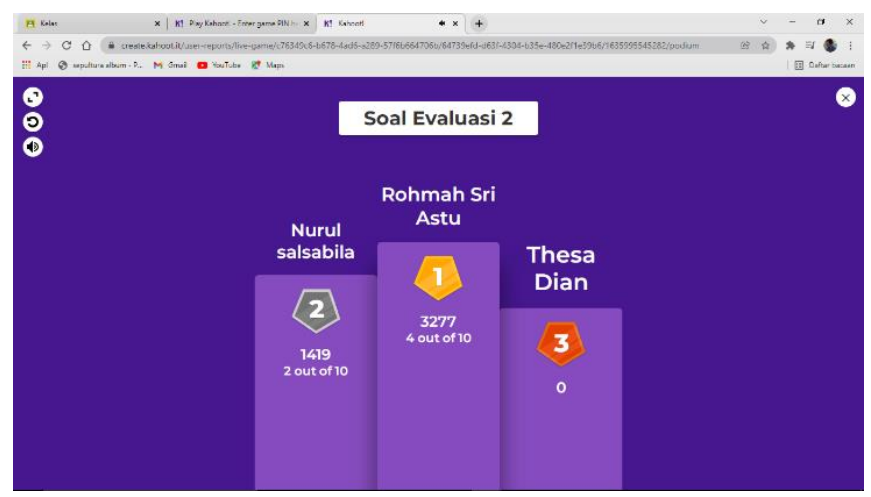

Gambar 4. Tampilan Perolehan Poin

3. Tahap Pengembangan (Development)

Tahap pengembangan menghasilkan draft final pengembangan aplikasi game Kahoot sebagai media evaluasi yang telah melalui revisi setelah adanya telaah dalam bentuk saran 
atau masukan dan validasi dari para validator, adapun pihak-pihak yang berperan sebagai validator yaitu : ahli materi dan soal Ibu Leny Christiana, S.Pd, ahli media Bapak Try Sudrajat, S.Pd, ahli evaluasi Bapak Sumardi, S.Pd.

Dan juga dilakukan implementasi media yang dilakukan di laboratorium komputer SMA Negeri 1 Malinau khususnya kelas XI MIPA 3 untuk menguji keefektifan dan kepraktisan dari aplikasi game Kahoot! yang dikembangkan.

\section{a. Kelayakan aplikasi game Kahoot! Sebagai media evaluasi hasil belajar siswa}

Hasil validasi dari ahli materi terhadap pengembangan aplikasi game Kahoot! pada mata pelajaran informatika pokok bahasan integrasi antar office mendapatkan hasil seperti pada tabel 3:

Tabel 3. Hasil Validasi Materi

\begin{tabular}{|l|c|c|}
\hline \multicolumn{1}{|c|}{ Variabel } & Persentase & Kriteria Kelayakan \\
\hline Ketepatan & $80 \%$ & Layak \\
\hline Kelengkapan & $80 \%$ & Layak \\
\hline Perhatian & $80 \%$ & Layak \\
\hline Dampak Bagi Siswa & $80 \%$ & Layak \\
\hline Dampak Bagi Guru & $80 \%$ & Layak \\
\hline Pemahaman & $80 \%$ & Layak \\
\hline Total Presentase & $\mathbf{4 8 0 \%}$ & - \\
\hline Rata-rata Persentase & $\mathbf{8 0 \%}$ & Layak \\
\hline
\end{tabular}

Berdasarkan tabel 3 dapat diketahui seluruh variabel pada hasil validasi materi yang meliputi variabel ketepatan, kelengkapan, perhatian, dampak bagi siswa, dampak bagi guru mendapatkan persentase hasil yang sama yaitu $80 \%$.

Sehingga validasi materi pengembangan aplikasi game Kahoot! pada materi konsep integrasi office mendapatkan persentase nilai rata-rata sebesar $80 \%$ (layak).

Selanjutnya hasil validasi dari ahli media mendapatkan hasil sebagai berikut :

Tabel 4. Hasil Validasi Media

\begin{tabular}{|l|c|c|}
\hline \multicolumn{1}{|c|}{ Variabel } & Persentase & Kriteria Kelayakan \\
\hline Keterbacaan & $80 \%$ & Layak \\
\hline Tampilan & $90 \%$ & Sangat Layak \\
\hline Huruf & $88 \%$ & Sangat Layak \\
\hline $\begin{array}{l}\text { Kemudahan Dalam } \\
\text { Penggunaan }\end{array}$ & $80 \%$ & Layak \\
\hline Total Presentase & $\mathbf{3 3 8 \%}$ & - \\
\hline Rata-rata Persentase & $\mathbf{8 4 . 5 \%}$ & Sangat Layak \\
\hline
\end{tabular}

Berdasarkan tabel 4 diketahui bahwa hasil validasi media pada variabel keterbacaan mendapatkan persentase $80 \%$ (layak). Variabel tampilan mendapatkan persentase $90 \%$ (sangat layak). Variabel huruf mendapatkan persentase $88 \%$ (sangat layak). Terakhir variabel kemudahan dalam penggunaan mendapatkan persentase $80 \%$ (layak). Media yang praktis ialah media yang mempertimbangkan aspek mekanisme penggunaan (Mustaqim, 2017). Sehingga pengembangan aplikasi game Kahoot! pada 
validasi media mendapatkan rata-rata persentase $84.5 \%$ (sangat layak). Terakhir hasil validasi dari ahli evaluasi mendapatkan hasil sebagai berikut :

Tabel 5. Hasil Validasi Evaluasi

\begin{tabular}{|l|c|c|}
\hline \multicolumn{1}{|c|}{ Variabel } & Persentase & Kriteria Kelayakan \\
\hline Ketepatan & $80 \%$ & Layak \\
\hline Kelengkapan & $80 \%$ & Layak \\
\hline Penulisan Soal & $80 \%$ & Layak \\
\hline Kualitas Soal & $80 \%$ & Layak \\
\hline Bahasa & $80 \%$ & Layak \\
\hline Total Presentase & $\mathbf{4 0 0 \%}$ & - \\
\hline Rata-rata Persentase & $\mathbf{8 0 \%}$ & Layak \\
\hline
\end{tabular}

Berdasarkan tabel 5 dapat diketahui seluruh variabel pada hasil validasi evaluasi yang meliputi variabel ketepatan, kelengkapan, penulisan soal, kualitas soal dan bahasa mendapatkan persentase hasil yang sama yaitu $80 \%$ (layak). Sehingga pengembangan aplikasi game Kahoot! pada validasi evaluasi mendapatkan rata-rata persentase $80 \%$ (layak).

b. Efektifitas aplikasi game kahoot! Sebagai media evaluasi hasil belajar siswa

Pada uji coba terbatas dilakukan di SMA Negeri 1 Malinau pada kelas XI MIPA 3 dengan jumlah 20 siswa. Dibagikan 10 soal pretest kepada siswa kemudian setelah penggunaan aplikasi game Kahoot dibagikan 10 posttest dengan kriteria soal yang sama. Hasil nilai dari pretest dan posttest siswa yaitu sebagai berikut :

Tabel 6. Hasil Pretest Posttest

\begin{tabular}{|l|c|c|c|}
\hline \multicolumn{1}{|c|}{ Nama } & Pretest & Posttest & Keterangan \\
\hline Siswa 1 & 50 & 80 & Tuntas \\
\hline Siswa 2 & 30 & 60 & Tidak Tuntas \\
\hline Siswa 3 & 40 & 100 & Tuntas \\
\hline Siswa 4 & 50 & 100 & Tuntas \\
\hline Siswa 5 & 60 & 100 & Tuntas \\
\hline Siswa 6 & 30 & 90 & Tuntas \\
\hline Siswa 7 & 60 & 100 & Tuntas \\
\hline Siswa 8 & 40 & 80 & Tuntas \\
\hline Siswa 9 & 30 & 80 & Tuntas \\
\hline Siswa 10 & 40 & 80 & Tuntas \\
\hline Siswa 11 & 40 & 90 & Tuntas \\
\hline Siswa 12 & 20 & 70 & Tidak Tuntas \\
\hline Siswa 13 & 50 & 90 & Tuntas \\
\hline Siswa 14 & 30 & 100 & Tuntas \\
\hline
\end{tabular}


Vol. 2 No. 1 Februari 2022, e-ISSN : 2797-0140 | p-ISSN : 2797-0590

\begin{tabular}{|l|c|c|c|}
\hline Siswa 15 & 10 & 70 & Tidak Tuntas \\
\hline Siswa 16 & 50 & 80 & Tuntas \\
\hline Siswa 17 & 40 & 100 & Tuntas \\
\hline Siswa 18 & 40 & 100 & Tuntas \\
\hline Siswa 19 & 60 & 100 & Tuntas \\
\hline Siswa 20 & 70 & 90 & Tuntas \\
\hline Total & $\mathbf{8 4 0}$ & $\mathbf{1 7 6 0}$ & \\
\hline Rata-rata & $\mathbf{4 2}$ & $\mathbf{8 8}$ & \\
\hline
\end{tabular}

Berdasarkan tabel 6 dapat diketahui setelah dilakukan pretest dapat diketahui jika rata-rata nilai pretest siswa adalah sebesar 42. Selanjutnya setelah dilakukan uji coba aplikasi game Kahoot! yang dikembangkan akan dibagikan kembali soal posttest untuk mengetahui seberapa sejauh perubahan hasil belajar yang diperoleh oleh siswa. Hasil posttest yang diperoleh siswa memiliki rata-rata nilai sebesar 88 .

Sehingga dari adanya peningkatan nilai pretest ke posttest siswa sebesar 46 maka penggunaan aplikasi game Kahoot! dapat meningkatkan hasil belajar siswa. Namun pada rata-rata nilai hasil pretest siswa masih belum dapat memenuhi ketuntasan klasikal, akan tetapi pada rata-rata nilai hasil posttest siswa sudah dapat memenuhi ketuntasan klasikal. Hal ini dapat terbukti dari jumlah siswa yang menjawab benar sebesar $\geq 61 \%$ setelah diberikan perlakuan. Persentase tingkat ketuntasan klasikal yang diperoleh sebesar $86 \%$ dimana 17 siswa dinyatakan tuntas dan 3 siswa belum tuntas.

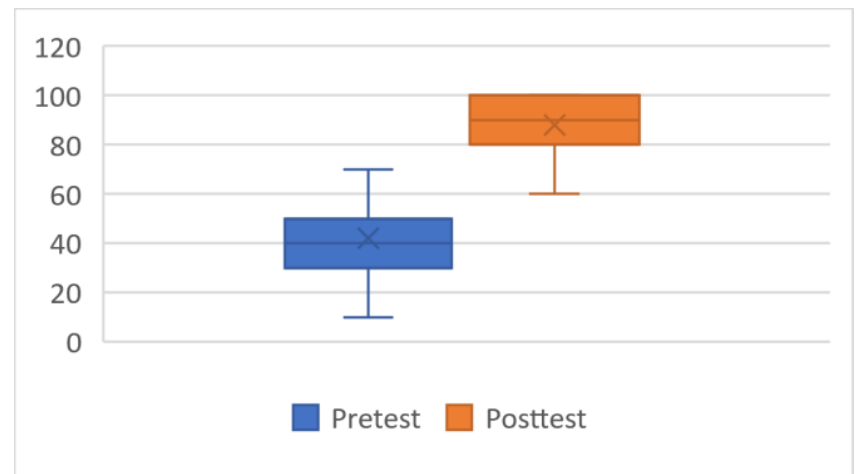

Gambar 5. Diagram Perubahan Pretest Posttest

Berdasarkan diagram diatas dapat dilihat bahawa terdapat adanya peningkatan hasil belajar siswa setelah menggunakan aplikasi game Kahoot!. Peningkatan hasil belajar dapat dihitung menggunakan $n$-gain dan diperoleh nilai sebesar 0.806 dengan kriteria "Tinggi".

c. Respon siswa terhadap penggunaan aplikasi game kahoot! sebagai media evaluasi hasil belajar siswa

Lembar respon peserta didik dibagikan melalui google form dan didapat hasil seperti pada tabel 7.

Tabel 7. Hasil Respon Peserta Didik

\begin{tabular}{|l|c|c|}
\hline \multicolumn{1}{|c|}{ Variabel } & Persentase & Kriteria Kelayakan \\
\hline Syarat Dikdaktik & $90 \%$ & Sangat Layak \\
\hline Syarat Kontruksi & $90 \%$ & Sangat Layak \\
\hline Syarat Teknis & $96 \%$ & Sangat Layak \\
\hline
\end{tabular}


Vol. 2 No. 1 Februari 2022, e-ISSN : 2797-0140 | p-ISSN : 2797-0590

\begin{tabular}{|l|c|c|}
\hline Total Presentase & $276 \%$ & - \\
\hline Rata-rata Persentase & $92 \%$ & Sangat Layak \\
\hline
\end{tabular}

Dari tabel 7 dapat diketahui hasil dari respon siswa yang dilakukan terhadap 20 siswa melalui google form diperoleh rata-rata keseluruhan komponen mendapatkan kategori "sangat layak" dengan persentase 92\% (sangat layak) yang terdiri dari syarat dikdaktik sebesar 90\% (sangat layak), syarat kontruksi sebesar 90\% (sangat layak) dan syarat teknis sebesar 96\% (sangat layak).

Penelitian pengembangan ini menghasilkan aplikasi game Kahoot! sebagai media evaluasi hasil belajar siswa di SMA Negeri 1 Malinau. Aplikasi game Kahoot! yang dikembangkan berisi soal-soal mengenai materi integrasi office dengan jumlah 10 butir soal, dimana setiap soal memiliki batas waktu untuk menjawab 30 detik sampai 60 detik. Perserta didik dapat menjawab soal kuis dengan memilih kode yang tertera pada aplikasi game Kahoot! melalui smartphone yang mereka gunakan. Setelah kuis selesai hasil skor yang diperoleh siswa dapat lagsung diketahui. Sehingga dari skor yang didapatkan oleh siswa dapat dijadikan guru sebagai media evaluasi hasil belajar siswa.

Penelitian pengembangan aplikasi game Kahoot! sebagai media evaluasi hasil belajar dilaksanakan di laboratorium komputer SMA Negeri 1 Malinau pada XI MIPA 3 dengan meteri integrasi antar office pada tanggal 23 November 2021. Respon yang ditunjukkan siswa saat penelitian sangat baik, siswa antusias dan tertarik pada penggunaan aplikasi game Kahoot! dalam pembelajaran, karena siswa belum pernah menggunakan aplikasi Kahoot! sebelumnya. Walaupun pembelajaran dilakukan melalui sistem daring tetapi tidak mengurangi antusias siswa.

\section{a. Kelayakan aplikasi game Kahoot! sebagai media evaluasi hasil belajar siswa}

Kelayakan aplikasi game Kahoot! sebagai media evaluasi hasil belajar siswa ini didapatkan dari kegiatan validasi kepada beberapa ahli seperti : ahli materi, media dan evaluasi. Kegiatan validasi ini sesuai dengan model pengembangan 4D pada tahap pengembangan (development), yang bertujuan untuk membuat draft menjadi suatu produk kemudian menguji validitasnya kepada para ahli dibidangnya. Berdasarkan hasil validasi dari ahli materi terhadap pengembangan aplikasi game Kahoot! pada mata pelajaran informatika pokok bahasan integrasi antar office mendapatkan rata-rata presentase $80 \%$ maka dapat dikatakan layak. Dalam penelitian ini validasi

bahasa tidak dilakukan peneliti, karena pada validasi materi sudah mencangkup komponen bahasa yang digunakan didalamnya sesuai pada pedoman Bahasa Indonesia yang baik dan benar.Berdasarkan hasil validasi media diperoleh rata-rata persentase skor sebesar $84 \%$, sehingga dari segi media pengembangan aplikasi game Kahoot sebagai media evaluasi hasil belajar ini dapat dikatakan valid dan sangat layak untuk digunakan.

Validasi ahli terakhir yaitu validasi evaluasi, pada validasi ini diperoleh rata-rata persentase skor sebesar $80 \%$ sehingga dapat dikatakan valid dan layak digunakan.

Rata-rata persentase skor dari keseluruhan validasi pengembangan aplikasi game Kahoot! sebagai media evaluasi hasil belajar siswa adalah 81,3\% dengan keterangan valid dan layak digunakan dalam pembelajaran.

Hasil validasi sejalan dengan hasil penelitian yang sudah dilaksanakan oleh Cahya Kurnia Dewi, yang berjudul "Pengembangan Alat Evaluasi Menggunakan Aplikasi Kahoot! Pada Pembelajaran Matermatika Kelas X" dengan presentase skor dari keseluruhan validasi yaitu $82 \%$ dengan keterangan valid.

\section{b. Efektifitas aplikasi game Kahoot! sebagai media evaluasi hasil belajar siswa}


Efektifitas aplikasi game Kahoot! sebagai media evaluasi hasil belajar siswa dapat dilihat melalui perubahan yang terjadi sebelum dan sesudah penggunaan aplikasi game Kahoot! dalam pembelajaran. Perubahannya adalah pencapaian ketuntasan belajar siswa. Semakin banyak siswa mencapai ketuntasan belajar maka semakin efektif produk yang dikembangkan.

Pada penelitian ini efektifitas aplikasi game Kahoot yang dikembangkan diperoleh peneliti dengan menggunakan pretest posttest yang diberikan kepada siswa. Pretest posttest ini diberikan pada kelas XI MIPA 3 yang berjumlah 20 siswa. KKM (kriteria ketuntasan minimum) yang ditetapkan peneliti adalah 75 sesuai dengan KKM (kriteria ketuntasan minimum) yang berlaku disekolah SMA Negeri 1 Malinau.

Berdasarkan hasil pretest posttest aplikasi game Kahoot! yang dikembangkan dapat dinyatakan efektif. Hal ini dapat ditunjukkan oleh persentase ketuntasan hasil belajar siswa. Sebelum menggunakan aplikasi game Kahoot! nilai rata-rata siswa sebesar 42 dan tidak satupun siswa yang mencapai ketuntasan belajar. Selanjutnya sesudah menggunakan aplikasi game kahoot! nilai rata-rata siswa menjadi 88. Sebanyak 17 siswa tuntas dan sisanya sebanyak 3 siswa masih tidak tuntas, sehingga persentase ketuntasan siswa sebesar $86,4 \%$ dengan kategori sangat baik.

Peningkatan nilai dari pretest ke posttest siswa sebesar 46 maka penggunaan aplikasi Kahoot! dapat dinyatakan mampu meningkatkan hasil belajar siswa. Peningkatan hasil belajar dapat dihitung menggunakan n-gain dan diperoleh nilai sebesar 0.806 dengan kriteria "Tinggi".

Penelitian terdahulu yang sejalan dengan penelitian ini berjudul pengaruh penggunaan media pembelajaran game edukasi kahoot! terhadap hasil belajar siswa kelas XI di SMAN 1 Blitar oleh (Setiawati, 2018) dengan hasil sebelum menggunakan Kahoot! nilai rata-rata siswa 51,87. Namun setalah menggunakan Kahoot! nilai rata-rata menjadi 74,33 .

\section{c. Respon siswa terhadap penggunaan aplikasi game Kahoot! sebagai media evaluasi hasil belajar siswa}

Respon siswa setelah menggunakan aplikasi game Kahoot! sebagai media evaluasi hasil belajar ini dapat dilihat dari jawaban siswa terhadap angket yang telah dibagikan. Angket yang dibagikan memuat beberapa syarat seperti : syarat dikdaktik, syarat kontruksi dan syarat teknis.

Angket respon siswa dibagikan kepada 20 siswa melalui google form. Hasil yang peroleh yaitu rata-rata keseluruhan komponen mendapatkan kategori "sangat baik" dengan persentase $92 \%$ yang terdiri dari syarat dikdaktik sebesar $90 \%$, syarat kontruksi sebesar $90 \%$ dan syarat teknis sebesar $96 \%$.

Hasil ini sejalan dengan pelitian (Ningrum, 2018) yang berjudul kuis interaktif berbasis game Kahoot! terhadap hasil belajar siswa yang memperoleh hasil bahwa dari 44 siswa sebanyak 38 siswa mempunyai respon yang baik terhadap penggunaan Kahoot!

Berdasarkan pengamatan peneliti saat proses pembelajaran dengan menggunakan aplikasi game Kahoot! sebagai media evaluasi hasil belajar siswa terlihat sangat antusias dan aktif walaupun pembelajaran dilakukan secara daring. Namun, terdapat batasan dalam penelitian ini yaitu aplikasi game Kahoot! memerlukan jaringan internet yang kuat, sehingga apabila terdapat siswa yang mengalami gangguan jaringan maka dapat menghambat kerja siswa dalam menyelesaikan tes.

\section{KESIMPULAN}

Berdasarkan penelitian yang telah dilakukan didapatkan hasil bahwa penggunaan aplikasi game Kahoot! valid, efektif dan praktis untuk dapat digunakan dalam pembelajaran sebagai media evaluasi hasil belajar. Hal ini karena aplikasi game Kahoot dapat digunakan 
sebagai media pembelajaran kuis interaktif yang sangat efektif, menyenangkan, dan membuat peserta didik lebih bersemangat dalam pembelajaran.

\section{DAFTAR PUSTAKA}

Arsyad azhar. (2013). Raja Grafindo Persada jakarta. Media Pembelajaran Edisi Revisi. 2013.

Chairudin, M., \& Dewi, R. M. (2021). Edukatif: Jurnal Ilmu Pendidikan. Pengembangan Bahan Ajar Buku Saku Digital Berbasis Problem Based Learning Pada Mata Pelajaran Ekonomi. 3(3), 951-962.

Fitri Rofiarti, \& Anisa Yunita Sari. (2017). TIK Untuk Paud: Penggunaan Platform "Kahoot" dalam Menumbuhkan Jiwa Kompetetif dan Kolaboratif Anak. Pedagogi: Jurnal Anak Usia Dini Dan Pendidikan Anak Usia Dini.

Graham, K. (2015). TechMatters: Getting into Kahoot!(s): Exploring a Game-Based Learning System to Enhance Student Learning. Loex Quarterly.

Harlina binti Ishak, Z. M. N. \& A. A. (2017). Pembelajaran Interaktif Berasaskan Aplikasi Kahoot dalam Pengajaran Abad Ke-21. Prosiding Seminar Serantau Ke-8 2017, 627635.

Iwamoto, D. H., Hargis, J., Taitano, E. J., \& Vuong, K. (2017). Analyzing the efficacy of the testing effect using Kahoot ${ }^{\mathrm{TM}}$ on student performance. Turkish Online Journal of Distance Education, 18(2), 80-93. https://doi.org/10.17718/tojde.306561

Mustaqim, I. (2017). Pengembangan Media Pembelajaran Berbasis Augmented Reality. Jurnal Edukasi Elektro. https://doi.org/10.21831/jee.v1i1.13267

Ningrum, G. D. K. (2018). Studi Penerapan Media Kuis Interaktif Berbasis Game Edukasi Kahoot! Terhadap Hasil Belajar Mahasiswa. Vox Edukasi: Jurnal Ilmiah Ilmu Pendidikan, 9(1), 22-27. https://doi.org/10.31932/ve.v9i1.32

Nuriyah, N. (2014). Evaluasi pembelajaran: Sebuah Kajian Teori. Jurnal Edueksos.

https://doi.org/10.1165/rcmb.2013-04110C

Setiawati, H. D. S. E. P. A. (2018). Pengaruh Kahoot! Terhadap Hasil Belajar Siswa Kelas XI Di SMAN 1 Blitar. Jktp, 1, 274.

Thiagarajan, S. A. O. (1974). Development for Training Teachers of Exceptional Childern: A Sourcebook. Indiana Univ, Bloomingtoon Center for Innovation In. 